\title{
DR. PhD Sipos Anna Magdolna:* Summum bonum az európai könyvtárügyben? Az európai integráció és a könyvtárak jogi szabályozása
}

\begin{abstract}
As a survey which was examining law regulations of public libraries led by UNESCO delegated Frank Gardner in the middle of 1960 s pointed, the laws governing library's operation are similar in several countries of the European continent but at the same time they are also aligning to the national specialities. In the recent past European council and EBLIDA analysed the same in the standardizing Europe. This survey came to the same conclusion, but showed even more similarities. The study introduces the factors determining the recent standardization processes of the Library case in Europe, line up the pros and contras against standard legal regulation and highlights similarity and diversity.
\end{abstract}

\section{Bevezetés}

Amikor az európai országok nagyobb részét magába foglaló Európai Unió kulturális ügyeiről beszélünk, akkor a közgondolkodás szintjén az Európai Unió tagországai számára napjainkban is mértékadó, a Római Szerződés 126. és 127. cikkében rögzített, a tagállamok autonómiájára vonatkozó akarat fogalmazódik meg. Ám éppen a kulturális ügyek meghatározó elemeit jelentö oktatási és szakképzési kérdések körül egyre inkább megjelennek a közös érdekeltségü ajánlások, irányelvek, általános elvek. Ebben azt láthatjuk, hogy a követendő minták révén az Európai Unió integrálódó gazdasága mind határozottabban fogalmazza meg a fejlődéshez szükséges emberi eróforrásokkal szembeni elvárásokat. E folyamat eredményeként az Unióban élö állampolgárok iskoláztatásának egyes területein, valamint szakképzésében is megindultak azok az azonos irányba ható integrációs folyamatok, amelyek ma már a tagországok számára a legföbb igazodási pontokat jelentik. Elegendö itt csupán a koherens szakképzési rendszer végrehajtására hozott általános alapelvekre, tanácsi határozatokra és ajánlásokra, illetve az azok megvalósulását szolgáló programokra, vagy a felsőoktatásban bevezetett bolognai rendszerre hivatkozni. Az utóbbi másfél évtized Európai Uniós fejlödési folyamatai - a versenyképesség és foglalkoztatottság megőrzésére, továbbá fejlesztésére, a tudás felértékelődésére, az életen át tartó tanulás igényére, az interkulturális jelenségekre vonatkozó elemzések és fejlesztési programok - azt mutatják, hogy a korábban még kizárólag az egyes tagállamok hatáskörébe tartozónak ítélt oktatáspolitika napjainkban egyre inkább a közösségi politika részévé válik.

Hasonlóan domináns jelenségek szemtanúi lehetünk az Európai Unió tagországainak egyéb kulturális ágazatait vizsgálva is. Jóllehet az oktatásra és a szakképzésre vonatkozó alapos kidolgozottság a kultúra más területeire még nem jellemző, de a koherencia irányába ható folyamatok már más szektorokban is érzékelhetöen megindultak. A kulturális integritás irányába ható folyamatok csírái már a szervezet létrejöttének korai éveiben megjelentek, ám a közösség történetében alapokmányi szinten elöször a Maastrichti Szerzödés foglalkozott a kultúra kérdéseivel. Így e jelenségek legfontosabb keretét az Európai Unió 1992. évi Maastrichti Szerződése rajzolta meg, a megvalósitást pedig a szerződés szelle-

\footnotetext{
•Egyetemi docens - Pécsi Tudományegyetem Felnöttképzés és Emberi Erőforrásfejlesztési Kar.
} 
mében szervezett programok, akciók adják. Mint például a mũvészeti területen az 1990ben megindított Raphaël-program, vagy az egyik legrégebbi, a kulturális örökség megörzésére valamint a könyv- és olvasáskultúra támogatására vonatkozó programok. E két utóbbi terület szükségszerüen érintette és érinti a könyvtárak tevékenységét, és feltétlenül elösegíti a könyvtárak társadalmi szerepének erösödését. E folyamatok és programok mellett az Európai Unió napjainkban is kitart a Maastrichti Szerződés alapelve mellett. Ennek értelmében az EU nem törekszik elöíró magatartás tanúsítására a tagországok irányában, a közösség továbbra is csupán a kapcsolatok szervezésében és erösítésében, valamint a kulturális élet ösztönzésében kiván szerepet vállalni. A döntési jogokat továbbra is a szuverén tagállamok gyakorolják. Ezt támasztja alá az EU kulturális magatartásának másik meghatározó jellemzöje, a szubszidiaritás elve, amelynek betartásához a közösség a legmesszebbmenőkig ragaszkodik.

Ezeknek az alapelveknek a tiszteletben tartása mellett is látnunk kell azonban azokat a folyamatokat, amelyek alakítóan hatnak az Európai Unió, illetve a térség országai kulturális szférájának szereplöire. Jóllehet az EU kulturális területen nem alkalmaz normativ szabályozókat, ám az EU ajảnlásai, irányelvei, programjai hatottak és hatnak a tagországok legmagasabb szintũ jogi szabályozásaira. A hasonlóságok egyértelmüen kimutathatók mind a törvények által kodifikált célokban, mind pedig a szakmai kérdésekben. Dolgozatunkban a kulturális terület egyik fontos ágazatára, a könyvtárak jogi szabályozására vonatkozó vizsgálódásaink eredményeit mutatjuk be abból a szempontból, hogy az egyes országok törvényi szabályozásában milyen közös és milyen eltérö vonások jelentek és jelennek meg Európa, illetve az Európai Unió integrációs folyamatai nyomán.

\section{A könyvtárügy jogi szabályozásának nemzetközi egységesülési folyamatai}

Az európai országok könyvtárainak fejlödése már az önálló közgyüjteményügy, illetve könyvtárügy létrejöttének kezdeti szakaszaiban több területen is hasonlóságot mutatott. Az azonos jegyek azonban akkoriban még nem az akaratlagos integráció nyomán jelentek meg, hiszen a világpolitikai folyamatok sem ebbe az irányba, hanem inkább ellenkezöleg, a dezintegráció felé haladtak. A XX. század második felében már mind határozottabban és a tudatos egységesítés szándékával jelentek meg az azonos irányba tartó folyamatok, és azok nyomán napjainkban az európai országok könyvtárügye - a számos nemzeti, történelmi hagyományból eredö és az ország jogi, közigazgatási berendezkedéséböl adódó sajátosság, különbözőség mellett - mind tartalmi, mind pedig szervezeti szempontból egyre meghatározóbban a koherencia jeleit mutatta. Az egységesülési jelenségek számára kedvező alapot teremtett egyrészről az egyetemes könyvtárügy fejlődése, másrésztől pedig a könyvtárszakmai tevékenységeknek és munkamódszereknek a világ egészére kiterjedő huszadik századi egységesülési folyamatai. A XX. század második felében, a föként az UNESCO (The United Nations Educational, Scientific and Cultural Organization) és az IFLA (The International Federation of Library Associations and Institutions), továbbá a FID (The International Federation for Information and Documentation) és az ISO (International Organization for Standardization) által gondozott nemzetközi konferenciák ajánlásai nyomán az új nemzetközi (Universal Bibliographic Control) és nemzeti bibliográfiai programok, valamint a megvalósításukra kidolgozott nemzetközi normatívák és ajánlások tovább erősítették a könyvtárak tevékenységi és szolgáltatási rendszerének nemzetközi egységesülését. Ebben a folyamatban a könyvtári és bibliográfiai munkára vonatkozó nemzetközi ajánlások, szabályzatok és szabványok mellett legalább ilyen fontos szerepet játszott a könyvtárak és azokon belül föként a közkönyvtárak jogi szabályozására kidolgozott nem- 
zetközi irányelvek közreadása. 1949-ben az UNESCO nyilatkozatot tett közzé a közkönyvtárak fenntartása és müködése törvényi szabályozásának szükségességéröl, majd az 1953. évi, a nigériai Ibadanban megtartott Egyetemes Könyvtárügyi Szeminárium ajánlásokat dolgozott ki arra vonatkozóan, hogy a könyvtári törvények mely kérdések szabályozására terjedjenek ki. Hasonlóan foglalt állást az IFLA Közmüvelödẻsi Könyvtári Szekciójának 1955. évi memoranduma, amely önálló fejezetben foglalkozott a könyvtári jogalkotás kérdéseivel. Az ötvenes évek közepén megfogalmazott nemzetközi ajánlások eredményeként a közkönyvtári ellátás jogi szabályozásában a világ több részén, egyebek között Európában is elörelépés történt. Az UNESCO és az IFLA kezdeményezései az egyes országok könyvtárügyének jogi, törvényi szabályozására termékenyitỏen hatottak. Ezt mutatta ki a 14 ország, közte több európai ország könyvtárügyének jogi szabályozásával foglalkozó, az 1970-es évek elején, Frank Gardner vezetésével, az UNESCO megbízásából végzett empirikus kutatás nyomán készített összehasonlító tanulmány (Gardner 1971).

A könyvtárak jogi szabályozásának nemzetközi tendenciáiban lényegi változást hozott az információs társadalom jelenségeinek felerösödése, a világ fejlett részẻn meghatározóvả válása, valamint a könyvtárak feladatainak az új társadalmi elvárásokhoz való igazítása. $\mathrm{A}$ már korábban is említett IFLA Közmüvelödési Könyvtári Szekciójának - a közmüvelödési könyvtári ellátás nemzetközi normativáinak kidolgozását megkezdő - 1955. évi memorandumát, az 1972-ben elfogadott és az UNESCO közmüvelödési könyvtári kiáltványára alapozott dokumentuma váltotta fel: az UNESCO/IFLA manifesztuma. Közreadása óta ezt a nyilatkozatot több alkalommal módosították, aktualizálták, legutóbb 1994-ben (IFLA/ UNESCO 1994). A dokumentum - több fontos szakmai elem mellett - ajánlásokat fogalmazott meg a könyvtárak jogi szabályozására, nemzeti és helyi finanszírozására, a könyvtári stratégiai tervek elkészitésére, a könyvtári hálózatok meghatározására és támogatására, valamint a szolgáltatási sztenderdek megállapitására. A tőrvényi szabályozás szükségességét világszerte tovább erösítette a szintén az IFLA és az UNESCO újabb közös ajánlásait tartalmazó, a közkönyvtárak szolgáltatásainak továbbfejlesztésére irányuló dokumentum, amely 2001-ben jelent meg (Gill 2001).

\section{A könyvtárügy jogi szabályozásának egységesülési folyamatai az Európai Unióban}

Az előzőknél kisebb régióban ugyan, de hasonló módosulásokat hoztak az európai egységesülési folyamatok, az Európai Unió expanziója és az ezek nyomán létrejövő európai kulturális kezdeményezések, együttmüködések. Az Európai Unió tagországainak könyvtári egységesülési folyamatait elsősorban az Európa Tanács, valamint EBLIDA (European Bureau of Library, Information and Documentation Associations) közös munkálkodása segíti és erösíti. Az integráció fontos állomása volt, hogy 2000. január 20-án Strasbourgban az Európa Tanács Kulturális Együttmüködési Bizottsága, valamint az EBLIDA közzétette a könyvtári jogszabályokra és a könyvtárpolitikára vonatkozó irányelveit (Council of Europe/EBLIDA 2000). A dokumentumban a két szervezet kifejezetten ajánlja és támogatja a tagállamok könyvtáraira vonatkozó és a tagországok hatáskörébe tartozó jogi szabályozás felülvizsgálatának megindítását. A revideálás egyaránt jelentheti a már meglévő jogszabályoknak az irányelvekhez történö igazitását, vagy - azokban a tagországokban, ahol nincs ilyen tartalmú törvényi szabályozás - a szükséges jogszabályok elkészítését. Az Európa Tanács és az EBLIDA közös ajánlása, az UNESCO/IFLA manifesztumához igazodva, megfogalmazta a 47 tagország könyvtári törvényeivel szemben elvárt minimális követelményeket. Eszerint a jogi szabályozás során a könyvtárpolitikai célkitüzéseket négy fơ területen ajánlott meghatározni: a vélemény- és információs szabadság biztosítása a könyvtári rendszer révén, a könyv- 
tárak szerepének elismerése a nemzeti könyv- és információpolitikában, a könyvtárak és a tudásipar kapcsolatának definiálása, továbbá a könyvtári örökség védelme. Az Európa Tanács és Goethe Intézet gondozásában, 1999-ben, Münchenben rendezett nemzetközi konferencia ajánlásai (Bohrer 2000) fogalmazták meg azokat a szakmai minimumokat, amelyekre az érintett országokban a törvényi szabályozásnak ki kell terjednie.

Az Európa Tanács és az EBLIDA kezdeményezése egyértelmüen termékenyitően hatott az Európai Unió országainak könyvtári törvényhozási folyamataira. Ezt tanúsítják az EBLIDA, valamint a Német Könyvtáros Egyesület közremüködésével, az Európai Unió tagországai körében a XXI. század első éveiben készített felmérés eredményei (Schleihagen 2008). Az empirikus vizsgálat kimutatta, hogy a könyvtárak jogi szabályozása a 25 Európai Uniós tagállam esetében, meglehetősen vegyes képet mutat. Míg egyes országokban a jogi szabályozás csak a nyilvános könyvtárakra terjed ki, addig más országokban a könyvtárak teljes rendszerét átfogó törvények vannak hatályban, amelyek magukba foglalják a különböző könyvtártípusok müködését és a közöitük lévö koordináció jogi szabályozását is. Hasonló mértékü eltéréseket tapasztaltak a normativ szabályozások részletességében is: egyes országokban a törvény a helyi hatóságok számára csupán a szolgáltatási sztenderdeket írja elö, míg más országokban átfogóan és részletekbe menően deklarálják a szolgáltatások típusait, minőségét, a hozzájuk tartozó normatívákkal együtt.

A felmérés szerint, az Európai Unióhoz tartozó 25 tagország kétharmadában van hatályban könyvtári szaktörvény, kilenc országban azonban nincs. Az utóbbi kategóriába tartozik: Németország, Franciaország, Írország, Luxemburg, Hollandia, Málta, Ausztria, Portugália és Ciprus. 16 EU-tagország rendelkezik önálló könyvtári törvénnyel, amelyeknek elsöprö többségében - összesen tizenöt országban - az utóbbi években megtörtént a könyvtárakra vonatkozó jogi szabályozás felülvizsgálata és - föként az információs társadalom szèlesedéséből eredő - új körülményekhez történö igazítása. Ebbe a tizenöt országból álló csoportba tartozik kilenc, egykor a keleti blokkhoz, mára pedig az Európai Unióba integrálódott ország: Észtország, Lettország, Litvánia, Lengyelország, Románia, Szlovákia, Szlovénia, Csehország és Magyarország. Ezekben az országokban az 1989. évi politikai változások nyomán át kellett alakitani a törvényhozás rendszerét, könyvtárszakmai vonatkozásban pedig reagálni kellett az új követelményekre: szaktörvényi szabályozásukat az információs társadalom kihívásaihoz kellett igazítani. Ȧm nem csupán a volt szovjet blokk országaiban vált szükségessé, hogy a társadalmi elvárások jelentős változásai miatt a könyvtári jogszabályokat módosítsák. Belgium, Dánia, Finnország, Görögország, Olaszország és Spanyolország esetében is aktualizálni kellett azokat, annak érdekében, hogy meg tudjanak felelni az információs társadalom által diktált követelményeknek. Így az önálló könyvtári szaktörvénnyel rendelkezö 16 EU-tagország közül csupán Nagy-Britanniában van még napjainkban is olyan könyvtári törvény hatályban, amelyet még az 1990-es éveket megelözỏen (1964) hagytak jóvá, és amelyet az európai uniós kooperációs folyamatok, valamint az információs társadalom kihívásai miatt nem dolgoztak át. Jóllehet itt sem maradt érintetlen a törvény eredeti szövege: 2001 áprilisában pontosították a jogszabályt. Meghatározták a közkönyvtárak kötelezõ szolgáltatásait és a könyvtáros egyesülettel közösen a változásókhoz igazitották a könyvtári sztenderdeket. A strasbourgi irányelvek figyelembevételével és a Bundestag Enquête Bizottsága a Kultúra Németországban (2005) programjának megerösitése nyomán az eddig könyvtári szaktörvényi szabályozással nem rendelkezö Németország több tartományában is megindult a törvényalkotási folyamat: BadenWürttemberg, Mecklenburg-Elöpomeránia, Hessen, Alsó-Szászország és Szász-Anhalt, Brandenburg, Türingia kezdte meg a politikai és szakmai egyeztetéseket. Mostanáig azonban csupán a legutóbbiban, Türịngiában készítették és fogadták el, 2008. július 3-án, a mindössze öt paragrafusból álló tartományi könyvtári tơrvényt (Simon-Ritz 2008). 
A fentiek azt mutatják, hogy a könyvtárak müködését biztosító jogi szabályozási folyamatok az egész európai kontinensen és egyre meghatározóbban egységes irányba fejlỏdnek. A szakmai kritériumokon túl a törvényi szabályozásnak fontos tulajdonsága, hogy az nem csupán a könyvtárak müködését, feladatait szabályozza, hanem egyben a könyvtárak felé megnyilvánuló politikai akarat és a társadalmi igény kinyilvánításának is fontos összetevője. Az elvégzett felmérés azt mutatta, hogy a törvényekben tükröződő politikai és társadalmi mentalitásban sok azonosság, hasonlóság, de egyben számos nemzeti sajátosság is kimutatható. Vannak országok, amelyek megközelítik az ideális szabályozást (például Finnország, Dánia, Nagy-Britannia), és vannak olyanok is, amelyek csak bizonyos területekre kiterjedő normákat állapítanak meg, mint ahogyan a vizsgált országokban több esetben nincs is könyvtári szaktörvény, ám ez a valóságban nem akadályozza a fejlett könyvtári kultúra kialakulását és müködését. Úgy tünhet, hogy a könyvtárakra vonatkozó jogi szabályozás esetében is a sokféleség az elfogadható európai norma. Legalábbis ezt látszik erősiteni az a sokszínüség, amelyröl a fentiekben szóltunk.

\section{Summum bonum az egységes európai könyvtárpolitika?}

A közelmúltban azonban ugyanazokban a szakmai körökben, amelyek még alig egy évtizede a könyvtárügy országonkénti önálló törvényi szabályozását szorgalmazták, új megközelítések jelentek meg, új szempontok merültek fel. A korábban egyértelmủen elutasított közös európai könyvtárpolitika és egységes könyvtári rendszer kérdése ma már nem mint elvetendő, hanem inkább nagyon is megfontolandó kérdésként fogalmazódik meg. Azoknak a szakmai és politikai köröknek, fórumoknak a részéröl, akik szorgalmazzák a kérdés újragondolását, a legfontosabb argumentációja az európai könyvtárak rendkívül heterogén helyzete. Véleményük szerint az ebböl adódó egyenetlenség erősen akadályozza az Európai Unió állampolgárainak egyenlő és korlátlan kulturális, oktatási és információs szabadságát, valamint a szabad véleménynyilvánítás jogának gyakorlását. Az egyenlőtlen fejlödést a nemzeti sajátosságokra, a hatalmon lévő kormányok könyvtárak iránti politikai attitüdjére, a gazdasági egyenlőtlenségekre vezetik vissza, ám a legfőbb okát mégis abban látják, hogy az európai országok mindössze kétharmada rendelkezik önálló könyvtári szaktörvénnyel. Ám jól látható az is, hogy az egyes országok szintjén történő jogi szabályozás sem oldja meg ezeket a problémákat, hiszen ahol létezik törvényi szabályozás, azok között az országok között is jelentős eltérések mutathatók ki.

Mára már úgy tünik, hogy az Európa Tanács és az EBLIDA közel egy évtizeddel ezelötti kezdeményezései nem voltak eléggé hatékonyak, csupán korlátozottan érték el céljukat. Többnyire azokban az országokban hoztak szakmai eredményeket, ahol korábban is megfelelő színvonalú könyvtári ellátásban részesültek az állampolgárok. Mivel átütő eredmények nem születtek, ezért az EBLIDA újabb irányokat kíván meghatározni. Ennek legfőbb oka, hogy mind politikai, mind pedig szakmai indokokból eredeztethetően, továbbra sem várható az Európai Bizottság tagországokra vonatkozó könyvtári törvényi direktíváinak megjelenése. Ezért - javaslatuk szerint - arra kellene törekedni, hogy úgynevezett „fehér könyv" jelenjen meg a könyvtáraknak az európai tudás-társadalomban betöltött szerepéröl. További feladat lehet javaslatok megfogalmazása arról, hogy az egyes országok mit tegyenek könyvtáraik fejlesztése érdekében. Az új irányok és tennivalók meghatározása érdekében nemzetközi párbeszéd indult el, amelynek föbb eseményeit és eredményeit a NAPLE (National Authorities on Public Libraries in Europe) -konferenciák jelzik. Az új koncepció megértéséhez az EBLIDA és az Osztrák Könyvtárak Szövetsége elnökének, Gerald Leitnernek a szavait hívjuk segitségül. „Ha egyesült Európát akarunk, olyan közös 
európai könyvtárpolitika létrehozásában kell gondolkodnunk, amely minden európai polgár számára egyenlõ és korlátlan hozzáférést biztosit az információhoz, a tanuláshoz és a kultúrához." (Leitner 2008).

Egységes, európai szintü könyvtárpolitikáról napjainkban még nem beszélhetünk, ám az egységesülési folyamatnak, a legjobb ötletek megvalósulásának mára már több, elsősorban digitális formában megjelenő eredménye van. A számos, részben közvetlenül a könyvtárakra, részben pedig az úgynevezett határ- és rokonterületekre vonatkozó programok talán legfontosabb kézzelfogható eredménye az Európai Bizottságnak a virtuális könyvtárak létrehozására vonatkozó kezdeményezése. A tervek megfogalmazására 2005. szeptember 30-án Brüsszelben került sor, amikor az Európai Bizottság közzétette az európai írott és audiovizuális örökség interneten való hozzáférhetöségének stratégiáját (IP/05/1202). A terv magába foglalja a könyvtárak, a levéltárak és más archívumok digitalizálásának, közkinccsé tételének programját, amely egyrẹszröl biztositja a széleskörü, a földrajzi távolságoktỏi, az épületektől, a nyitvatartási időtöl független hozzáférést, másrészről pedig a kulturális vagyon és közkincs megörzésének fontos eszköze. A feladat nagyságrendjét jól mutatja, hogy csak a könyvtárakban örzött dokumentumállomány megközelíti a két és félmilliárd nyomtatott kiadványt, ám azokon túl a program kiterjed más médiumok - filmek, fényképek, kéziratok, zenemüvek, müsorarchívumok stb. - digitalizálására és közzétételére. Az Európai Unió valamennyi tagországára kiterjedő program első lépéseit jelenti az egyes nemzetek dokumentumait reprezentáló metaadatok digitális konverziója és a dokumentumállományok digitalizálása.

$\mathrm{Az}$ egyes nemzetek digitális könyvtárainak továbbfejlesztését jelentette a Google Könyvtár európai riválisának is tekintett, jelenleg mintegy négymillió dokumentumot tartalmazó Európai Digitális Könyvtár (Europeana) közelmúltbeli létrejötte. A rendkívül érdekes és hasznos kezdeményezést dinamikus fejlesztési tervek viszik tovább, és mára az EU „i2010” vezető projektjévé vált. A tervek szerint 2010-re mintegy 10 millió írásos és egyéb dokumentum online hozzáférését biztosítja majd a virtuális kollekció. Ám az EU tagországok gyüjteményeinek teljes körü online hozzáférése ma még csupán az ideák szintjén létezik. Az Európai Unió felmérése szerint a nemzeti könyvtárak állományának mindössze egy százaléka érhető el teljes szöveggel az interneten, és a vonatkozó digitalizálási tervek szerint ez az arány még 2012-ben is csupán a gyüjtemények négy százalékát fogja kitenni. Mindemellett az Európai Digitális Könyvtár kialakítása és müködtetése számos tartalmi és technikai kérdés megoldásának szükségességét hozta felszinre. Olyanokat is, amelyek nemzetközi szintü szabályozása sok esetben a nemzeti tradíciók, szabályok ellen hat, de az integrált virtuális gyuujtemény megvalósítása érdekében meg kell találni a megoldásokat. Szükségessé vált a digitalizálandó mennyiségre vonatkozó tervek összehangolása, és további pénzügyi forrásokat kellett és kell majd még a jövőben biztositani a digitalizálás elvégzésére. Komoly kihivást jelent, hogy a legtöbb tagországban még nem áll rendelkezésre a digitális tartalom megörzésének módszertana, technológiai háttere és az ahhoz szükséges szakértelem, amely elengedhetetlen lenne ahhoz, hogy a digitális tartalmak a jövő generációi számára is hozzáférhetök maradjanak. Külön kezelendö problémát vet fel a kompatibilitás kérdése. Annak érdekében, hogy a különféle adatforrások és adatbázisok kompatibilisek legyenek az Europeana rendszerével, illetve az utóbbi által felhasználhatók legyenek, közös normákat, szabványokat kell alkalmazni. Megoldást kell találni a szerzöi jogi kérdések problémáira is.

Jóllehet Európában ma még nem beszélhetünk egységes könyvtárpolitikáról $\mathrm{s}$ föként egységes jogi szabályzásról, mégis azt látjuk, hogy az Európai Unió különböző szintủ elvi deklarációi, állásfoglalásai, koncepciói, ajánlásai, javaslatai, tervei és nem utolsósorban az Europeana létrehozása, valamint fejlesztési koncepciója laza rendszerré kezdi összefüzni a 
tagországok könyvtárait. A rendszerré szerveződésnek ma még csupán csirái fedezhetők fel a nemzeti, illetve a nagyobb könyvtárak együttmüködésében, ám a modell váza már elkészült, és a szolgáltatási tartalmak további erösödése feltétlenül a virtuális egységesülés felé viszi a könyvtárakat, és - reményeink szerint - nem csupán a könyvtári, hanem az egyéb gyüjteményeket is. A könyvtárak és más gyüjtemények virtuális egyesítése a metaadatok egységesítése a könyvtárak, a múzeumok, a levéltárak és az audiovizuális gyüjtemények az intézmények legfontosabb, központi eleme felöl, az állomány dokumentumai, valamint az azokról készült metaadatok oldaláról közelít az integrációhoz. A legerösebb, legfontosabb intézményi részrendszerek integrációja - várhatóan - magával húzza majd ebbe a folyamatba magukat az intézményeket is.

\section{Irodalomjegyzék}

Bohrer, Christiane (2000): Bibliotheksgesetzgebung in Europa : Diskussionsbeiträge und Länderberichte $=$ Library legislation in Europe : discussion papers and country reports Europarat, Goethe-Institut, Bock und Herchen. Bad Honnef.

Council of Europe/EBLIDA (2000): Guidelines on Library Legislation and Policy in Europe In. http://209.85.129.132/search?q=cache\%3ApznpOmtRESoJ\%3Awww.bibliotheksportal.de\%2Ffi leadmin\%2F0bibliotheken\%2FBibliothek_der_Zukunft\%2Fdokumente\%2Feuroparat_eblida 2000.pdf+Strassbourg $+2000+$ eblida\&hl=hu\&gl $=$ hu

Gardner, Frank M. (1971): Public library legislation: a comparative study. UNESCO. Paris.

Gill, Philip et al. (2005): A közkönyvtári szolgálat : Az IFLA és az UNESCO fejlesztési irányelvei. Könyvtári Intézet. Budapest. In. http://archive.ifla.org/VII/s8/news/pg01-hu.pdf

IFLA/UNESCO (1994): Public Library Manifesto In. http://archive.ifla.org/VI//s8/unesco/eng.htm

Leitner, Gerald (2008): Könyvtári törvények Európában - közös európai könyvtárpolitika kialakitása felé. In. Könyvtári Figyelö, 54. évf., 2008. 3. sz. pp. 477-480.

Schleihagen, Barbara (2008): Bibliotheksgesetze in Europa : Mittel politischer Steuerung und Gestaltung In. Bibliothek: Forschung und Praxis, 32. Jg., 2008. Nr. 1. pp. 14-20.

Simon-Ritz, Frank (2008): Der Thüringer Weg zu einem Bibliotheksgesetz In. Bibliothek: Forschung und Praxis, 32. Jg., 2008. Nr. 3. pp. 318-325. 